\title{
The rock art of Tastet Cave (Sainte-Colome, Pyrénées-Atlantiques, France): at the crossroads of the Late Glacial artistic traditions
}

L'art pariétal de la grotte Tastet (Sainte-Colome, Pyrénées-Atlantiques, France): au carrefour des traditions artistiques tardiglaciaires

Diego Garate, Olivia Rivero, Raphaëlle Bourrillon and Jean-Marc Pétillon

\section{OpenEdition}

\section{Journals}

\section{Electronic version}

URL: http://journals.openedition.org/paleo/2858

DOI: 10.4000/paleo.2858

ISSN: 2101-0420

\section{Publisher}

SAMRA

\section{Printed version}

Date of publication: 15 December 2013

Number of pages: 103-120

ISSN: 1145-3370

\section{Electronic reference}

Diego Garate, Olivia Rivero, Raphaëlle Bourrillon and Jean-Marc Pétillon, «The rock art of Tastet Cave (Sainte-Colome, Pyrénées-Atlantiques, France): at the crossroads of the Late Glacial artistic traditions », PALEO [Online], 24 | 2013, Online since 04 September 2015, connection on 07 July 2020. URL : http://journals.openedition.org/paleo/2858 ; DOl : https://doi.org/10.4000/paleo.2858

This text was automatically generated on 7 July 2020. 


\title{
The rock art of Tastet Cave (Sainte- Colome, Pyrénées-Atlantiques, France): at the crossroads of the Late Glacial artistic traditions
}

\author{
L'art pariétal de la grotte Tastet (Sainte-Colome, Pyrénées-Atlantiques, France): \\ au carrefour des traditions artistiques tardiglaciaires
}

Diego Garate, Olivia Rivero, Raphaëlle Bourrillon and Jean-Marc Pétillon

Many thanks to Mr Pierre Tastet, owner of the cave, for allowing us to undertake field operations and providing us with all the facilities for it. Also thank you to all the excavation team and scientific team of the 2012 and 2013 campaigns, and to G. Marsan and J. Omnès for documents and information they have provided us with. The 2012 and 2013 excavation campaigns were funded by the Ministry of Culture (DRAC Aquitaine); the 2013 campaign was also funded by the Archaeological Group of the western Pyrenees. Some archaeological data of the Arudy basin used here were obtained through the Magdatis project (project ANR 2011 BSH 3 0005, director J.-M. Pétillon). We also wish to thank the ANR PREHART (director C. Fritz) whose work, in progress, now allows to progress notably on the issue of the archaeology of decorated caves.

1 Located in the Bearn part of the Pyrenees, at the mouth of the Ossau Valley, the Arudy basin was subjected, as early as the second half of the $20^{\text {th }}$ century, to numerous archaeological excavations that allowed highlighting an intense and prolonged frequentation by Late Glacial hunter-gatherer groups of the Middle and Upper Magdalenian (Marsan 1979a, 1979b, 1996). On a territory of hardly ten square kilometres, centred on the small town of Arudy, at least eight caves are known today with traces of human occupations during a period that can be archaeologically dated between 18,000 and 15,000 cal BP (see below). Some of these sites yielded very rich archaeological assemblages, especially in portable art work (Espalungue and SaintMichel caves: Thiault and Roy 1996 - p. 192-196 and 293-297). 
2 However, surprisingly, this important core of Magdalenian settlement is not associated with any large parietal art organisation. This contrasts with what is generally found in the Pyrenean Magdalenian where the most important habitation sites are in close relationship with decorated assemblages - including, among others, from east to west, the cave of Gazel (Sacchi 1986; Sacchi et al. 2005), the sites of Niaux and La Vache (Clottes 1995; Clottes and Delporte 2003), Mas d'Azil (Péquart and Péquart 1960-1963; Delporte 1979; Alteirac and Vialou 1980), the Volp caves (Begouen and Breuil 1958; Clottes 1989; Begouen et al. 2009), the cave of Gourdan (Fritz, Tosello, Pinçon 1996) or again the caves of the Gaztelu hill (Isturitz, Haristoya-Oxocelhaya and Erberua: Passemard 1924, 1944; Saint-Perier 1930, 1936; Larribau and Prudhomme 1989; Pétillon 2006; Larribau 2011). From this point of view, the Arudy basin represents an interesting configuration in the context of a general reflection on the relationship between habitation sites and decorated Magdalenian caves. Therefore, the detailed study of one of the rare known rock art in this area is even more interesting, and is an essential step prior to any further discussion. This study is the subject of the present article.

3 Tastet cave (named after its owner) ${ }^{3}$, near the village of Sainte-Colome, yielded the only assemblage of parietal art currently identified in the Arudy basin. Reported in the early 1970s (Minvielle 1970), it was the object, at the beginning of the 1980s, of two detailed tracings that agreed on an attribution to A. Leroi- Gourhan's "style IV", corresponding to the middle or upper Magdalenian (Omnès 1983; Blanc and Marsan 1984). A reexamination of these representations, however, was necessary for several reasons. Firstly, the changes in tracing methods in the last thirty years (Fritz and Tosello 2007) offered the possibility of a revised reading of the lines; this reading was also intended to discuss some differences between the two existing tracings (see below). In addition, new knowledge obtained in recent decades on several large Magdalenian parietal art sites should allow to replace the art of Tastet cave more precisely in its chronological and regional context (Begouen et al. 2009; Clottes 1995; Garate and Bourrillon 2012; Garate et al. 2012; Garate and Ríos 2012; Groenen et al. 2012; Vialou 1986; etc.).

This review was also motivated by conservation reasons. The decorated panel is not currently protected; the cave is known and accessible, it is not closed and will not be. The risk of degradation of the engravings is real. In addition, C. Blanc and G. Marsan (1984) already noted: "it seems that the red ochre is disappearing gradually, by leaching of the wall." It was therefore important to gather as complete as possible documentation on these threatened parietal graphics. 
Figure 1 - Magdalenian sites in the Arudy basin. 1: Malarode 1 and Malarode 2; 2: Laa 2; 3: le Bignalats; 4: le Poeymaü; 5: Espalungue; 6: Saint-Michel; 7: Tastet and Samson caves (IGN map on http://www.geoportail.fr, 1/25000 scale; location of sites modified after Marsan 2009). Bottom right: location of the Arudy basin on the northern side of the Pyrenees (map: E. Gaba, wikimedia commons).

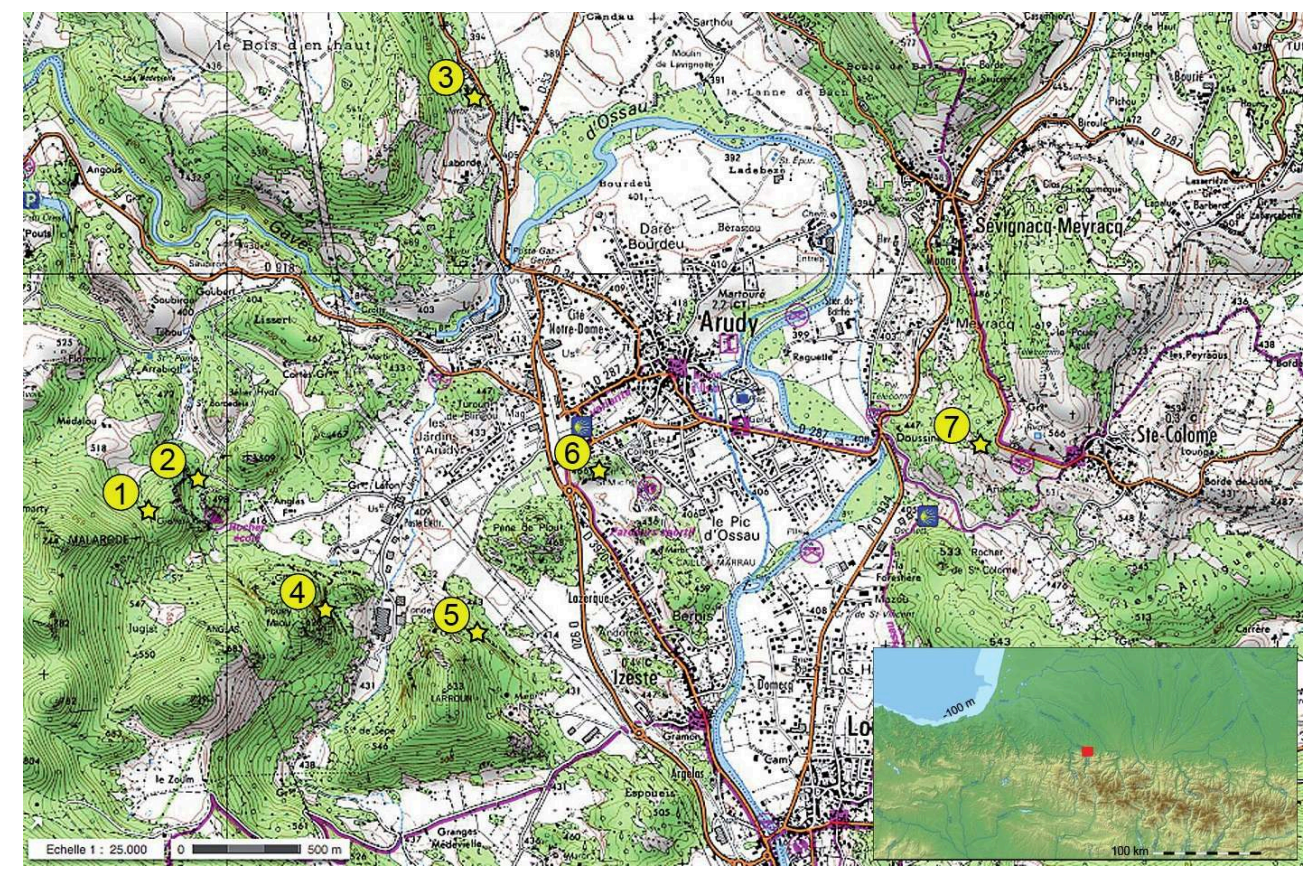

5 This work was also facilitated by a favourable scientific context. Indeed, it fits in a research project led since 2007 by one of us (DG), dedicated to the revision of the parietal art of the Basque Country in order to better understand the relationships between the graphic expressions of Cantabria and of the Magdalenian Pyrenees (Garate and Bourrillon 2012; Garate et al. 2012). The study of the Tastet cave is one among a series of on-going analyses on several sites in the Arudy basin (revision of the ancient series, new dating...) under the Magdatis project - a project also led, since 2011, by one of us (JMP), and dedicated to the middle and upper Magdalenian of western Aquitaine (Langlais et al. 2012). This project is itself fed by recent field data, particularly from the excavation of the Magdalenian levels of Laa 2 cave, west of Arudy (Dumontier and Courtaud 2008; Dumontier et al. 2011; Dumontier and Pétillon 2012). Finally, the tracing of the parietal art was made in direct connection with a planned excavation: two sounding campaigns (resp. JMP) were carried out in Tastet cave in June-July 2012 and July 2013, a few meters away from the decorated area, offering the opportunity to address simultaneously the study of parietal drawings and that of the portable remains - without anticipating, of course, their contemporaneity.

\section{1 - The Tastet cave: local context and presentation}

\section{1 - The Magdalenian occupation of Arudy}

On the territory of the municipality of Arudy, more than half a dozen caves with traces of Palaeolithic occupations are known, sometimes very anciently (fig. 1). All are between 450 and $500 \mathrm{~m}$ in altitude and yielded a series of remains, often very rich, related to the Middle and/or Upper Magdalenian (Bahn 1984). The following can be 
mentioned: Espalungue Cave, excavated by F. Garrigou and L. Martin (1864) and then by É. Piette (1907), followed by several other researchers until the early twentieth century; Saint-Michel Cave (Mascaraux 1910); the Cave of the Hermit, briefly mentioned by P. de Mortillet (1912 - p. 127); the two caves of Malarode (Fonteneau 1922) and the Cave of Poeymaü (Laplace 1953; Livache et al. 1984). More recently, G. Marsan resumed the excavation of the caves of Espalungue and Malarode 1 (Marsan 1985) and undertook the excavation of the shelter of Bignalats (Altuna and Marsan 1986; Marsan 1988); the latter was also excavated by G. Laplace (1981). The excavations conducted from 2006 to 2010 by P. Dumontier in the cave of Laa 2 have also shown the presence of an important sequence of Magdalenian occupation (Dumontier and Pétillon 2012).

7 The absolute chronology of the Magdalenian occupations of the Arudy basin is currently under revision in the context of the Magdatis project. The data available in the middle of 2013, still largely unpublished, include seven "classic" radiocarbon dates (by beta counting) and 23 AMS dates. The latter allowed to globally locate the Arudy Magdalenian occupation between 14,570 \pm 65 BP (or 18,020-17,390 cal BP4; OxA-26672) and 12,552 $\pm 83 \mathrm{BP}$ (or 15,140-14,220 cal BP, Erl-11112) - these two dates corresponding to the extremes (the basis of the Middle Magdalenian and the top of the Upper Magdalenian) of the currently most complete sequence, in Laa 2. Some evidence of older human occupations than the Middle Magdalenian exists, but it is rare and remains to be characterised precisely. After the end of the Upper Magdalenian, the Azilian is found in the Arudy basin in Espalungue ("layers with flat perforated harpoons made of deer antlers": Piette 1907), in the Poeymaü (BS and CPE layers: Laplace 1953; Marsan 1979b) and very probably in the Bignalats (layer Cbg-ni: Marsan 1988) caves.

\section{2 - Location and description of the cave}

On the eastern slope of the Arudy basin, the municipality of Sainte-Colome is known for hosting two caves frequented in the Palaeolithic (a third cave is sometimes mentioned: Blanc and Marsan 1984).

9 The first one, Samson cave (from the owner's name), is dug into an Aptian limestone bar oriented approximately NW-SE, showing on about $2.5 \mathrm{~m}$ high in the middle of marl and shale formations and about $100 \mathrm{~m}$ higher than the current Gave d'Ossau river. Explored in the 1870s and in 1925, the cave has yielded elements of lithic and bone industry of the Upper Palaeolithic (Magdalenian? Mortillet 1912 - p. 127; Minvielle 1970 - p. 307). 
Figure 2 - General map of Tastet cave showing the terminal gallery. Modified after topography by T. Barragué in Omnès 1983.

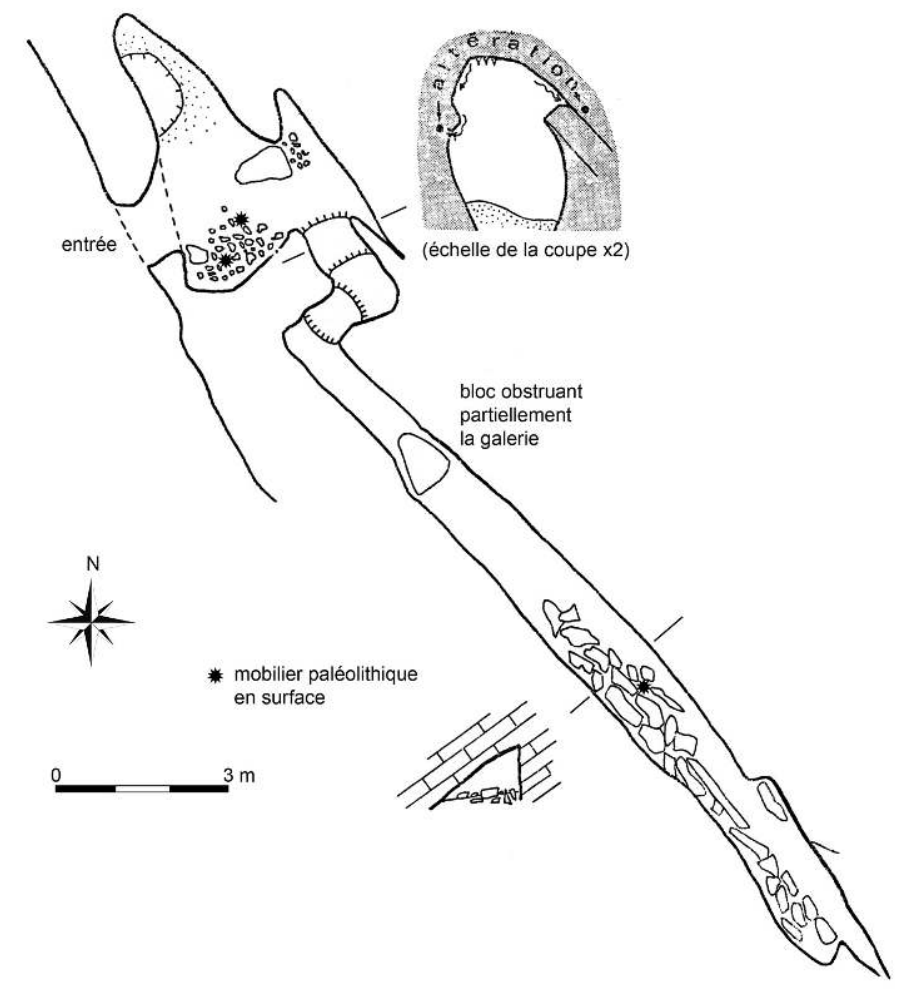

10 Tastet cave opens in the same limestone bar, fifty meters to the southeast. The current entrance, facing west, is about $512 \mathrm{~m}$ in altitude; when the land was a meadow - that is to say until the 1990s - this entrance offered a panoramic view of the Arudy basin, especially on the hills on the western side where the other caves occupied in the Magdalenian are found. This view is now obscured by vegetation. The entrance to the cave is currently in the form of an opening about $0.5 \mathrm{~m}$ high and $1 \mathrm{~m}$ wide. It gives access to a room about ten square meters in size, entirely but weakly lit by daylight, the vault being barely $2 \mathrm{~m}$ high at the most (fig. 2; fig 3). The floor of the room is relatively flat, except at the southeast extremity, separated by a projection about fifty centimetres high. At this point, about $1 \mathrm{~m}$ high on the wall, the entrance of a sub horizontal gallery, half a meter in diameter, opens up. It continues on about fifteen meters in length, in a NW-SE axis, before dividing into several impassable galleries. In its first part, this gallery is dug into the limestone and has no sedimentary infill. In its second part - beyond a large block that partially obstructs it - the floor is made up of a pile of large collapsed limestone blocks on a depth of at least $2 \mathrm{~m}$. At this level, the gallery section is triangular, with a ceiling whose inclination - about $50^{\circ}$ - follows the one of the first room. 
Figure 3 - Map and section of the entrance room, showing the location of the decorated panel (topography by G. Parent, October 2012).

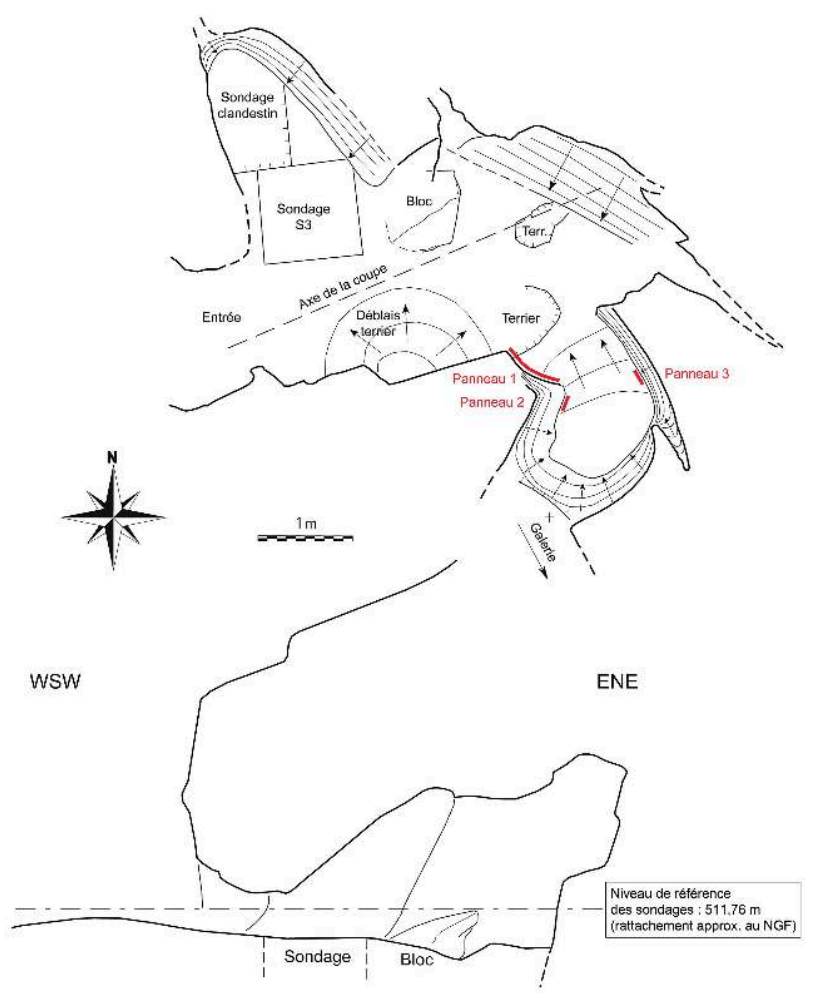

11 The first known intervention in Tastet cave is an illegal trench, done in the 1970s and extending on about half a square meter in an alcove north of the entrance. Thereafter, in the early 1980s, J. Omnès (1983) collected a flint scraper and some remains of Pleistocene fauna (a reindeer bone) on the floor of the cave. During an inspection in the cave in 2002, C. Normand was also able to collect on a cone of debris at the entrance of a burrow, reindeer bones and elements of lithic and bone industry (Normand, pers. com.). These clues have led to a scheduled survey campaign in 2012 and 2013 (Pétillon et al., 2012). The results of this operation are up to date only giving a partial view of the archaeological potential of the cave. It may however be noted that several archaeological assemblages were identified in the cave and on the slope at the entrance; they indicate the presence of an Upper Magdalenian with scalene triangles, as it is known and documented in the French southwest (Langlais, 2010), but they also yielded older evidence (likely Middle Magdalenian). The first results of the geomorphological study also suggest that the porch of the cave was probably more advanced in the Late Glacial - the present-day small cave only being, in this case, the "bottom" of a formerly larger cave - and the configuration of the entrance was different (without being able, for the moment, to confirm or precise this assumption).

\section{2 - The decorated assemblage}

\section{1 - History}

The rock art of Tastet cave was discovered on $1^{\text {st }}$ January 1967 by the speleologist P. Minvielle and reported by him a few years later: "[...] I had the good fortune to discover in a nearby cave rock paintings (bison, horse) of Magdalenian aspect" (Minvielle 1970 - 
p. 308). Ten years later, following an indication of J. Omnès to J. Clottes, Tastet cave was mentioned for the first time under the name of "cave of Sainte-Colome" in an inventory of decorated Palaeolithic French caves (Clottes 1980- p. 80). In subsequent years, two tracings of the painted and engraved panel were made and published: one by J. Omnès $(1982,1983)$ and one by a team from the Archaeological Group of the western Pyrenees (Blanc and Marsan 1984).

C. Blanc and G. Marsan focused on the main panel, while J. Omnès described several decorated areas. In addition, the reading of the figures of the main panel diverged somewhat between these two publications. The authors agreed on the identification of most of the patterns: a red ochre stain in the upper part of the panel; an engraved horse, facing left; an oval pattern (eye?) engraved above the horse's neck; the fore body of a bison with horns represented. But in the detail, the reading of the drawings was different, as is shown in the tracings (fig. 4), and differences exist in the identification of some patterns (one possible horse head for C. Blanc and G. Marsan; one isolated eye and a hind leg for J. Omnès). These differences, as well as the old age of these works, explained the need for a thorough revision of the decorated sector of the cave.

Figure 4 - The main panel in the Tastet cave: top, drawn after J. Omnès (after Omnès 1982, 1983 and a paper printing sent by $\mathrm{J}$. Omnès); bottom, after $\mathrm{C}$. Blanc and G. Marsan (after Blanc and Marsan 1984).

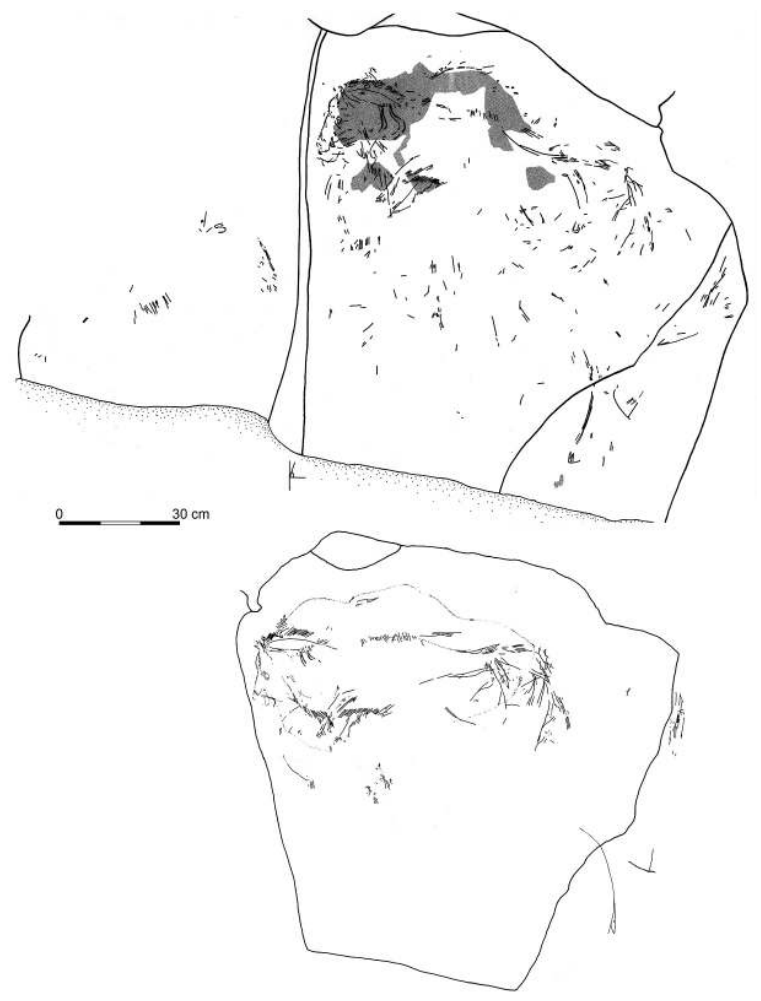

\section{2 - Description}

The decorated part of the cave is concentrated in the first room south of the entrance, in a very small space of $2 \times 3 \mathrm{~m}$ by $1.5 \mathrm{~m}$ high. 
Figure 5 - The decorated area (picture E. Croidieu).

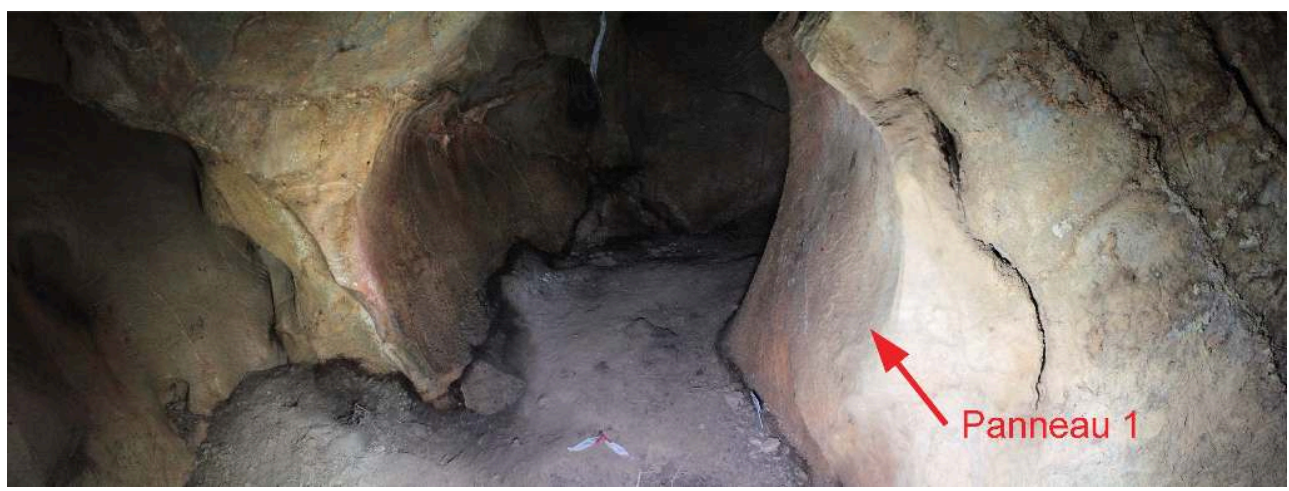

On the western wall (on the right going towards the back of the cave), two decorated panels follow each other (fig. 5); the first one comprises almost all the representations. On the eastern wall (on the left going towards the back of the cave), many red stains are visible and appear to be, by their dispersion, their colour and morphology, natural flows of iron oxide from the host rock.

Figure 6 - An overview of the panel 1. Picture taken from the opposite wall (picture 0. Rivero).

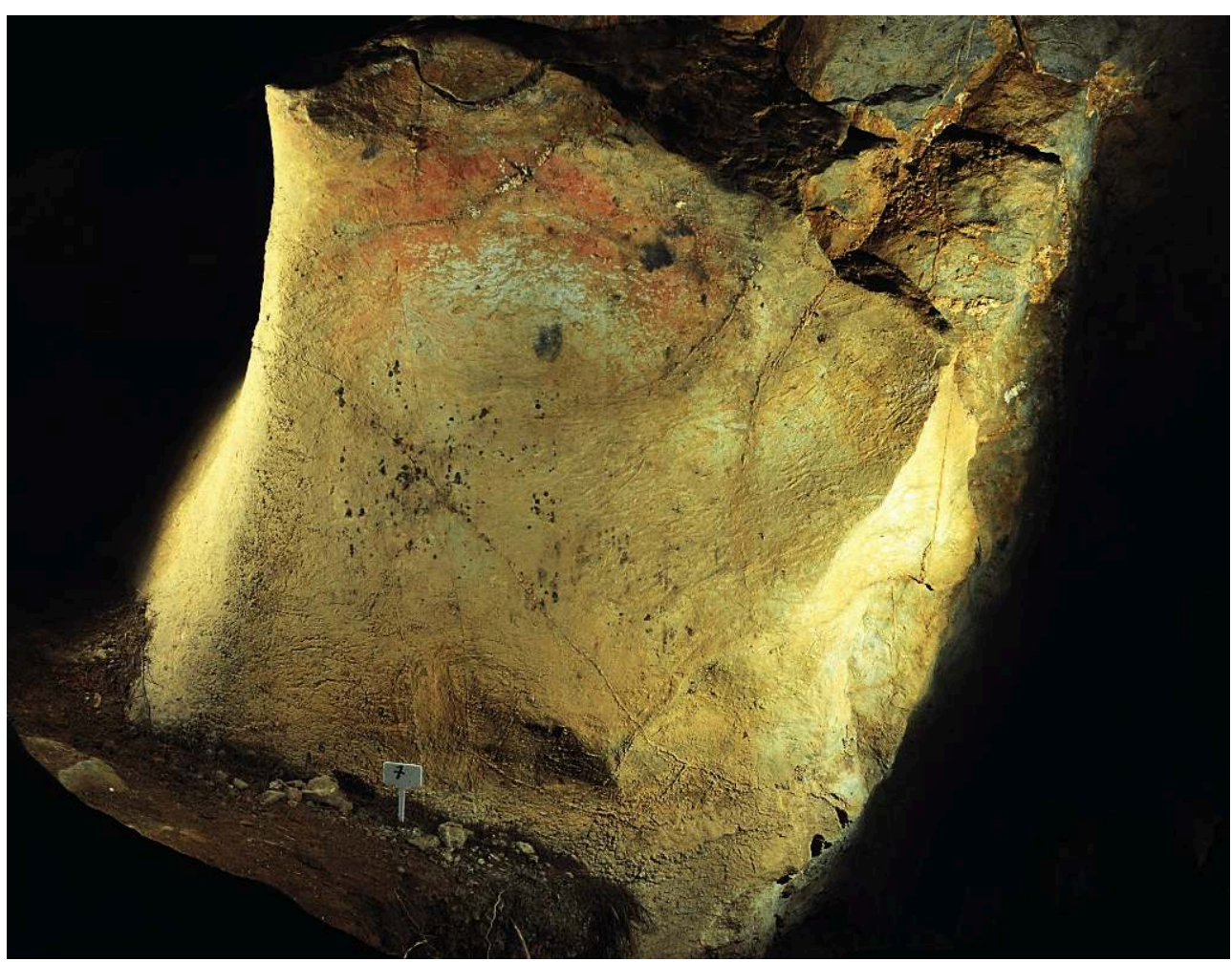

16 The first decorated panel of the cave is located at the intersection of the entrance room with an axial gallery. It is a natural concavity about $96 \mathrm{~cm}$ wide and $110 \mathrm{~cm}$ high (fig. 6). In its upper part, a horizontal edge defines the support and its right end makes an angle of $90^{\circ}$. On the left, the edges of the concavity are slightly rounded.

Subsequent alterations of the Palaeolithic graphic activity, natural for most, are visible. Thus, part of the red pigments used for the drawing of a bison has almost disappeared, partly because of the very small amount of matter applied to the wall. The engravings, extremely fine, were done on a thin calcite layer covering the middle part of the panel. 
Partial removals of the calcite erased some engraved lines. Finally, in the lower part of the panel, some fine animal scratching and some carbide stains are visible.

The graphic composition is better preserved in the upper panel (fig. 7). The choice of this support was not a random one, as shown by the use of the upper edge of the panel in the drawing of the cervico-dorsal line of a red bison. Other entities were added by superimposition, engraved, all oriented to the left, that is to say towards the bottom of the cave.

Figure 7 - Tracing of the panel 1 (0. Rivero, R. Bourrillon, D. Garate).

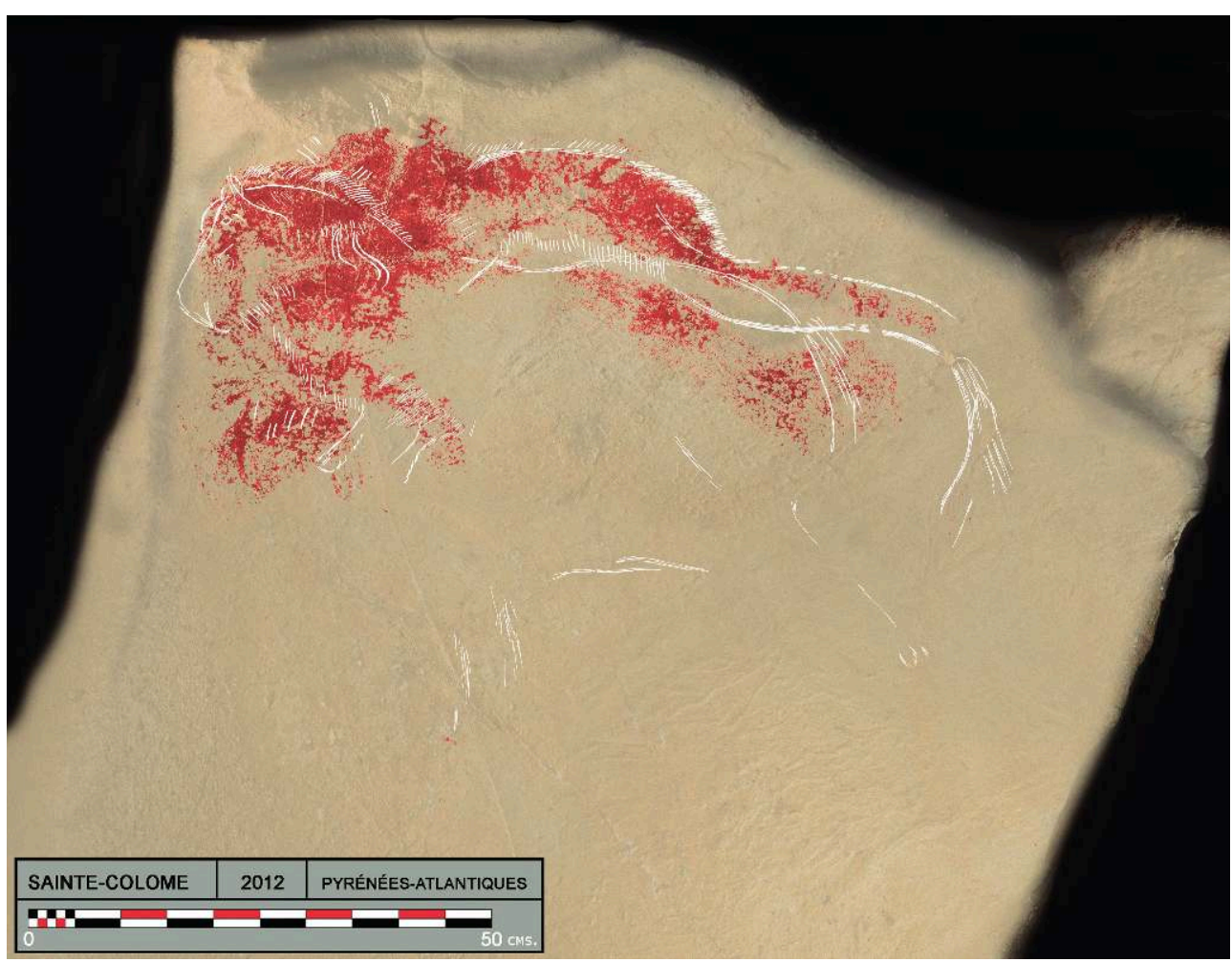

- Figure of a bison, painted and engraved ( $\left.\mathrm{n}^{\circ} 1.1\right)$ in left profile (fig. 8)

Dimensions: 115 x $26 \mathrm{~cm}$

Height to the floor: $100 \mathrm{~cm}$

Only the upper part of the bison remains. A red tint area combined with fine incisions represents it. The cervico-dorsal outline and the head were painted in red at first; then engravings added and/or highlighted other anatomical elements (contour of the dorsal arch, hatching of the beard and hindquarters, one horn? and the eye?). Some isolated lines could be the remains of the representation of the front legs and the line of the belly but their poor preservation does not allow being affirmative. Engraving is multiple and fine for the cervico-dorsal contour, while the hatched lines figuring the coat are short and parallel, especially fine. Finally, the lines that draw the beard are slightly wider.

21 The bison is at the upper limit of the panel, taking advantage of the natural form of the rock in which it is possible to see the hindquarters and the beginning of the buttock (not engraved). 
- Engraved horse figure ( $\left.\mathrm{n}^{\circ} 1.2\right)$ in left profile (fig. 8)

Dimensions: 66 × $21 \mathrm{~cm}$

Height to the floor: $93 \mathrm{~cm}$

Figure 8 - Graphic composition of the panel 1 (0. Rivero, R. Bourrillon, D. Garate).

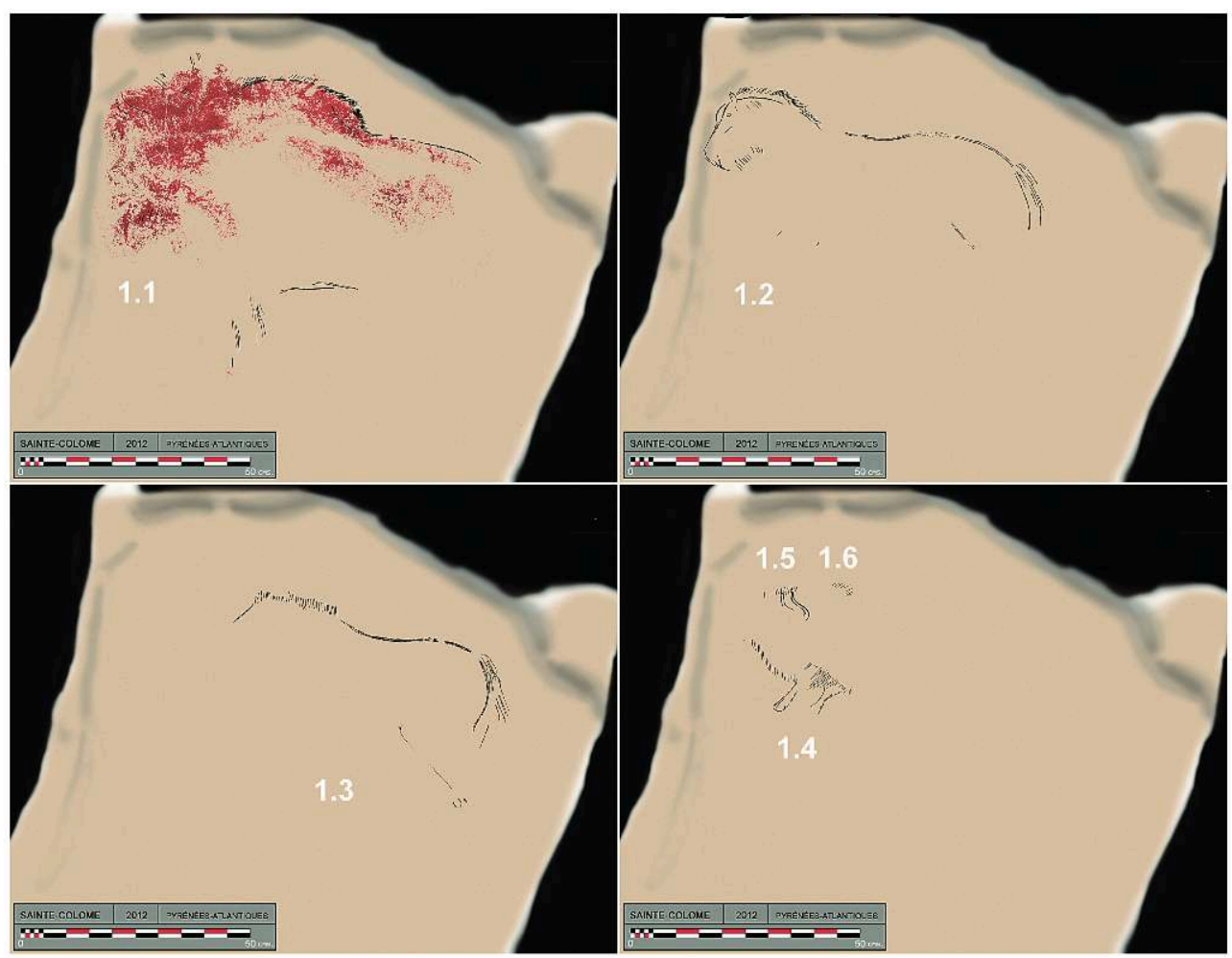

23 This horse is in the upper part of the panel; it is superimposed on the bison figure $\mathrm{n}^{\circ}$ 1.1. Only the upper half is still identifiable with the head, ear, eye, fronto-nasal line, muzzle, beard (hatched), mane, cervico-dorsal line, hindquarters and tail. The lower part has disappeared due to the flaking off of the surface layer of the wall. Some isolated lines may represent hind legs. The incisions are fine and multiple passes are visible on the cervico-dorsal and fronto-nasal lines.

24 - Engraved horse figure ( $\left.\mathrm{n}^{\circ} 1.3\right)$ in left profile (Fig. 8)

Dimensions: 50 × $8 \mathrm{~cm}$

Height to the floor: $90 \mathrm{~cm}$

25 This second horse figure is superimposed on the previous (1.2) and only the top part is still visible with the fronto-nasal line, the ear, the hatched mane, the cervico-dorsal line, the hindquarters and the tail. Some remains of drawings can possibly be attributed to the representation of the hind legs, one of them with a shoe. The incisions are extremely thin and several passing of the tool are visible.

26 - Engraved bison figure ( $\left.\mathrm{n}^{\circ} 1.4\right)$ in left profile (fig. 8$)$

Dimensions: $23 \times 26 \mathrm{~cm}$

Height to floor: $90 \mathrm{~cm}$

27 This figure, in the centre of the $\mathrm{n}^{\circ} 1.1$, shows no overlapping tracing relative to the rest of the figures that may be indicative of a stratigraphy of the graphic elements. 
the front part of the bison is drawn with two winding horns, a series of lines that seem to make the dorsal hump, hatching for the beard and the two front legs (very detailed, including notably the illustration of the coat and the cloven shoe). Although this figure is in the most damaged part of the panel, no engraved line indicates that the rear end was ever represented. From a technical perspective, this bison shows a variety of lines so far unidentified on this panel. Indeed, the horns were engraved by large deep lines, unlike the legs, finer and more superficial. The lines of the coat are equally fine and shallow, most likely achieved by a single passing of the tool.

- Short and parallel hatched lines ( ${ }^{\circ} 1.5$ and 1.6), isolated and engraved (fig. 8)

Maximum length: $8 \mathrm{~cm}$ and $5 \mathrm{~cm}$

30 These lines are located under the horns of the bison $n^{\circ} 1.4$ and cannot be connected to any of the preceding figures.

$31 \quad$ - Series of vertical engraved lines ( ${ }^{\circ} 1.7$; fig 9.)

Maximum length: $41 \mathrm{~cm}$

32

These lines are located in the right part of the panel and fit into a small concavity. They seem to correspond to the tail of the bison $\mathrm{n}^{\circ} 1.1$ if one follows the natural shape of the wall.

33

- Three engraved lines ( $\mathrm{n}^{\circ} 1.8$; fig 9)

Maximum length: $16 \mathrm{~cm}$

34

Two lines form a cross sign. A third incision, vertical and slightly curved, is visible on the left of the latter. These engravings are at the bottom right of the main panel and on another plane of the wall. No relationship with the other figures has been recognized.

The second panel $(82 \times 62 \mathrm{~cm})$, slightly concave, is very altered because of its position (it is located on the lower part of the wall and directly in the path that one takes to move towards the back of the cave). Only a limited group of lines could be identified in the central part of the panel.

- A series of hatched, parallel engraved lines ( ${ }^{\circ} 2.1$; fig 9)

Maximum length: $15 \mathrm{~cm}$ 
Figure 9 - Engraved series 1.7 et 1.8, engraved hatchings 2.1 et engraved transverse 3.1 (pictures and tracings R. Bourrillon, D. Garate, O. Rivero).

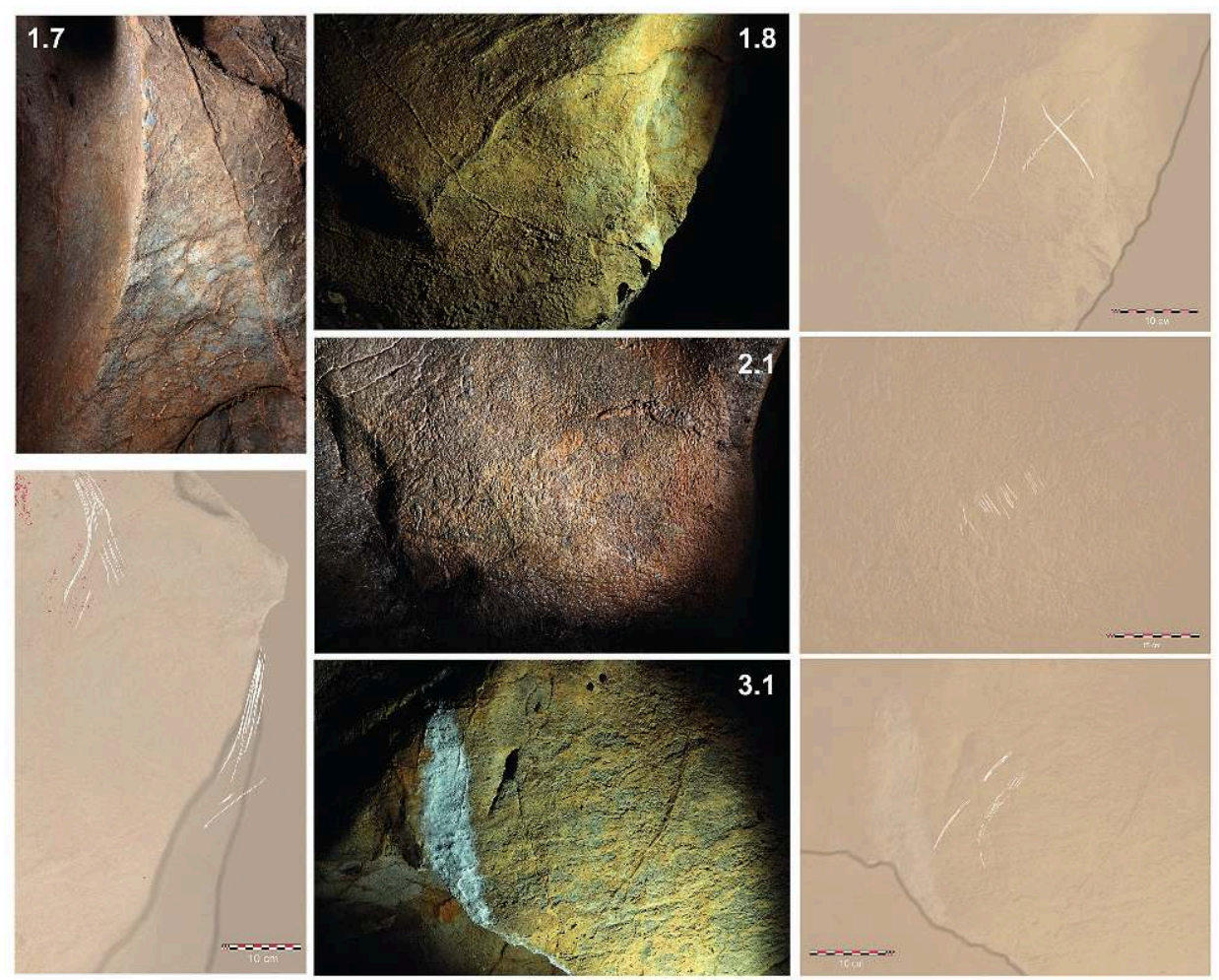

These lines could be the remains of a mane or fur of an animal, today unidentifiable. The engraving shows similarities with the figures of the panel 1 , in the profile and depth of the lines.

In the third panel (opposite panel 2), in a small recess, several finely engraved lines on a layer of calcite can also be observed ( $n^{\circ} 3.1$; maximum length: $13 \mathrm{~cm}$; fig. 9).

To the left of this third and final panel and in front of the main panel, on a convex wall, several evanescent red stains of natural origin (natural precipitation of hematite) are visible. They are similar to other red stains noted on the ceiling, at the entrance of the cave.

\section{3 - Summary}

The study of the rock art from Tastet cave allowed identifying 10 drawings, essentially figurative zoomorphs with more or less fragmentary representations. Signs are absent (except for a cross pattern). The species represented, classic, bison and horse, are easily identified by the presence of exclusive characteristics, and isolated patterns seem to correspond to fragments of figures of the same type.

41 Although parts of the engraved elements are poorly preserved, the "incomplete" nature of animal figures of Tastet cave is also intentional and within the field of graphic convention. Indeed, horses are represented only by the upper body (head, mane, cervico-dorsal line, tail and hindquarter line), and the bison $n^{\circ} 1.4$ is only represented by its anterior part. Only the largest figure, bison $\mathrm{n}^{\circ} 1.1$, which fits in the natural shape of the wall, was probably represented whole, although the current state of the wall only allows identifying isolated parts. The internal details are almost absent, notably the 
sensory organs (eyes, nose, mouth). However, in the case of bison $n^{\circ} 1.4$, some details such as the S-shaped horns or the shoe show a higher degree of elaboration with respect to the other figures.

These figures are represented in fine engravings, in some cases accompanied by red flat tints. A slight variation in the making of the engravings can be noted. Contours superimposed on painting (e.g. those of bison $n^{\circ} 1.1$ ) show multiple passing of the tool forming a wide but shallow groove: the lines are more scraped than engraved, a technique that allows enhancing the contrast between engraving and painting. However, the outline of exclusively engraved figures is narrower, although also drawn by multiple passing of the tool. The lines engraved by a single passing ( $\mathrm{V}$ profile and shallow) are, for their part, used for hatching showing the mane and beard. In some cases, they are wider incisions with a flat profile. Finally, in the case of the horns of the bison $n^{\circ} 1.4$, the engravings are deep, with a V-profile, deepened by several passing of the tool. Regarding painting, it is used only as a filling for the bison figure $\mathrm{n}^{\circ} 1.1$ and it was applied before the engraving in a diluted form.

According to the reading of the superimpositions of the engravings, the bison $\mathrm{n}^{\circ} 1.1$ was done first. The other figures are all, in fact, superimposed on it. The horse $\mathrm{n}^{\circ} 1.2$ was then engraved, followed by the $\mathrm{n}^{\circ} 1.3$ and, most likely, by the bison $\mathrm{n}^{\circ} 1.4$ (see fig. 8). Although all the figures are turned to the left, and that the largest of them (1.1) appears to serve as a "frame" for the others, their organization is not obvious. They seem "accumulated", one above the other.

Finally, the red stains and the "engraved head" reported by J. Omnès - identified respectively at the entrance and in front of the main panel, then on panel 2 - are natural traces and therefore have not been included in this study.

\section{3 - Sainte-Colome at the crossroads of the artistic traditions of the Late Glacial: Cantabria, Dordogne and the Pyrenees}

The rock art of Tastet cave presents a series of characteristics (technical and formal) widespread during the Late Glacial in the Pyrenees and the Cantabrian region (Sieveking 1979; Fritz, Tosello, Sauvet 2007; Garate 2009).

From a technical point of view, the first aspect to highlight, from the study of the art, is the painting/engraving combination. Engraving is used to emphasize the contour of the painted figures, a well-known technique, among other things, in the Magdalenian for representing bison (Sauvet and Tosello 1998). There are outstanding examples of the use of this combination of techniques in the Cantabrian region (Peña Candamo, El Pindal, Castillo and Altamira) and in the Pyrenees (Marsoulas, Bédeilhac, Fontanet) and the Dordogne (Font-de-Gaume). At Tastet cave, it is a bison painted in red and engraved $\left(\mathrm{n}^{\circ} 1.1\right.$, cf. fig. 10). The use or inclusion of a relief in a figure is another technique that develops throughout the Upper Palaeolithic and widely during the Magdalenian (Sieveking 1979). The most notable cases are found in the caves of Covaciella, Santimamiñe, Lumentxa, Ekain, Oxocelhaya, Labastide and Bédeilhac, or again the Trois-Frères cave where a bison is represented inverted, thus taking advantage of the natural form of the support (and Sauvet Tosello 1998). 

representations) is most unusual for the Pyrenees and would be closer to the western Pyrenees and Cantabria (Garate and Ríos 2012) including the caves of Sasiziloaga, Sinhikole, Alkerdi, Lumentxa or even Cullalvera or Moros San Vítores. Moreover, these assemblages are, like in Tastet cave, mainly composed of figures of horses and bison and without structured signs. Finally, in some cases, as in Lumentxa or Alkerdi (nearby shelter to Berroberría), Magdalenian occupations associated with the parietal representations are known. These small assemblages contrast with the great Magdalenian sanctuaries of the Cantabrian region and especially of the Pyrenees around the Ariège (e.g., Peña de Candamo, Llonín, Tito Bustillo in Asturias, Castillo, Altamira in Cantabria, Ekain, Altxerri in the Basque Country; Labastide, Marsoulas, The Trois-Frères, the Tuc d'Audoubert, Niaux, Bédeilhac or Montespan on the northern slopes of the central Pyrenees).

More specifically, although all the figures that make up the main panel of Tastet cave are now incomplete, some formal details allow stylistic comparisons with representations attributed to Middle Magdalenian Pyrenean contexts.

coincidence, as has been shown statistically in the case of cut-out contours on hyoid bones (Buisson et al. 1996).

but also for the beard, dewlap and coat of the dorsal hump of the bison. According to recent studies, hatched horse manes are to be considered as a proper formal marker of the middle Magdalenian of the Pyrenees, as opposed to double and linear manes specific of the upper Magdalenian of the Dordogne (Rivero and Sauvet in press). Similarly, the representation of contours and internal details of bison through hatching combined with lines is also characteristic of the Pyrenean region during this period (Rivero 2009). These are discriminatory elements of the "Niaux" morphotype according to analyses conducted by J. Fortea et al. (2004). Finally, these various markers can be linked with other details such as the representation of the bison hooves or the combination of painting and engraving previously emphasized.

middle Magdalenian of the Pyrenees, they are not exclusive to this region. Indeed, these characteristics were widely shared and disseminated. Thus, outstanding examples of these stylistic features can be found in the parietal art of Asturias (El Pindal, Tito Bustillo), Cantabria (Altamira) or in the Basque Country (Ekain) and in Périgord (Rouffignac; Plassard 1999).

Although nowadays it is still difficult to differentiate the parietal art of the Middle Magdalenian from the one of the Upper Magdalenian, the analysis of the formal characteristics of the bison and horses representations in the Tastet cave reveals that the most likely chronology for this assemblage is that of the classic middle Magdalenian. 
Figure 10 - Formal et technical details for the figures of the panel 1. a) Detail of the mane hatched of horse 1.2 and the horns in S of bison 1.4 (white arrows). b) Hoof of bison 1.4. c) Detail of the engraved traces of the croup of bison 1.1, superimposed on red painting. We can see how the traces recut the spot of painting (pictures O. Rivero, R. Bourrillon, D. Garate).

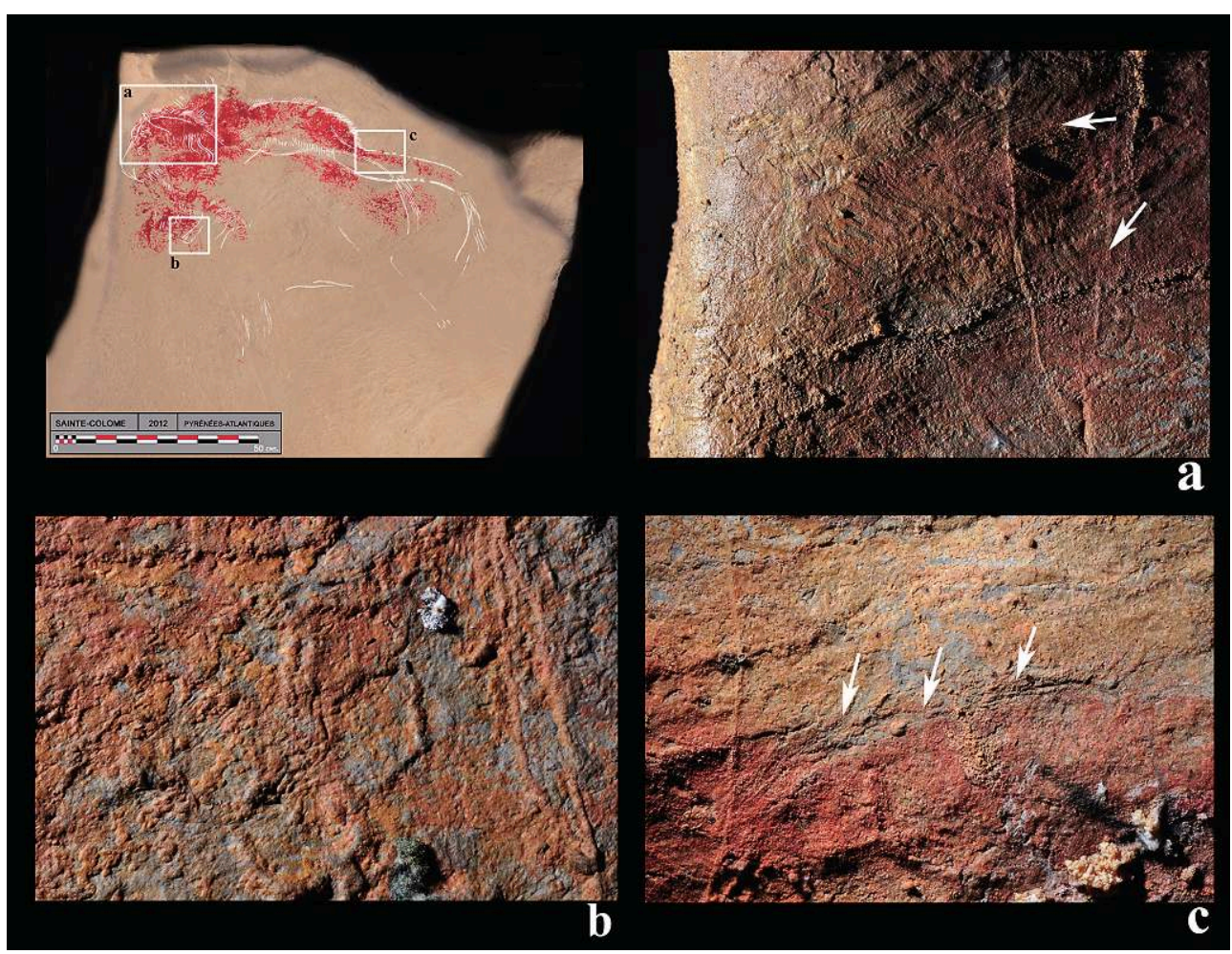

\section{Conclusion}

The revision of the artistic assemblage of Tastet cave in Sainte -Colome presented here has allowed us to verify and clarify the visible differences in the previous tracings, to better understand the characteristics of the formal and technical representations that had not been reported (the red stain that had not been identified as part of the great painted and engraved bison, the use of the natural shape of the support).

This deeper understanding of the representations allowed us also to specify more precisely the chronology of the assemblage, and to assign it to the Middle Magdalenian from the identified formal and technical characteristics.

Finally, we were able to assess the state of degradation of the limestone surface support and its impact on the parietal ornamentation. This protective approach was one of the objectives of the study and allowed us, among other things, to distinguish in the reading of the figures what originates from a poor conservation of the engravings or from a stylistic characteristic.

56 As seen, the parietal art of the Tastet cave in Sainte -Colome is part of a broader cultural group that can be attributed to the Middle and Upper Magdalenian, whose characteristics are largely shared by the Cantabrian, Pyrenees and Perigord sites (fig. 11).

57 Several recent studies have shown that these three regions, which gather the majority of the decorated caves, were, during the Middle Magdalenian, a real exchange network 
for the transmission of ideas, of stylistic models and technical concepts, both in the parietal art as in portable art (Fortea et al. 2004; Fritz, Tosello, Sauvet 2007; Tosello et al. 2007; Sauvet et al. 2008; Rivero 2009; Rivero and Hernando, in press). In this context, the role played by some sites at the crossroads of the three major regions seems particularly significant. This is the case, for portable art, mostly of the site of Isturitz and, for parietal art, of the caves of the Gaztelu Hill (Isturitz, Oxocelhaya and Erberua), of caves of the Arbailles Mountains (Etxeberri, Sasiziloaga and Sinhikole) and of Tastet cave. The study of the latter is part of a renewal of the graphic documentation of these assemblages (Garate et al. 2012).

In such a context, it seems all the more surprising that, as we mentioned at the beginning of this article, no large decorated assemblage has been discovered in the Arudy basin or in its immediate vicinity. We cannot completely exclude the possibility that this parietal art remains to be found in other caves. Anyway, this situation contrasts with the richness of several sites of Arudy in the field of portable art especially Espalungue and Saint -Michel - but also with the importance of the decorated caves located both to the west (the caves of Arbailles, about fifty kilometres from Arudy) and to the east (Labastide, a hundred kilometres away).

These variations may reflect the complexity of land use in the Late Glacial in the western Pyrenees (Chauchat 1999; Clottes 2003; Dachary 2006, 2009). A deeper understanding of the phenomenon of rock art, linked to the archaeological context of the decorated caves, is probably needed to better understand the characteristics of the sites and the links between them. In this perspective, the continued excavation of the archaeological levels of the Tastet cave could better document the relationship between the achievement of the parietal art and the occupation of the cave by the human groups.

\section{NOTES}

3. In the first publication, the site is not named and is simply referred to as a "cave" (Minvielle 1970 -p. 308). J. Omnès (1982 - p. 139) also speaks of "one of the small caves of Sainte-Colome." J. Clottes (1980), then C. Blanc and G. Marsan (1984), are the ones who use the term "cave of SainteColome" to describe the decorated cave. However, we preferred the name "Tastet cave" proposed by J. Omnès (1983) to avoid confusion with the neighbouring Samson cave, also located on the territory of the municipality of Sainte-Colome and that yielded Palaeolithic remains. The name "Tastet cave" is also consistent with the PIGMA name (http://sig.cartogip.fr/ donnees_culturelles).

4. The dates were calibrated using the software Calib 6.0 (http://calib.qub.ac.uk/calib/) with the IntCal09 curve (Reimer et al. 2009). The results are given with an interval of two sigmas. 


\section{ABSTRACTS}

Since 2012, Tastet Cave (Sainte-Colome, Pyrénées-Atlantiques) is the subject of a new research program led by one of the authors (JMP). This program offered the opportunity to restudy the parietal art from this site. The parietal art in Tastet Cave has been known since the 1970s; its restudy by three of the authors (DG, OR and $\mathrm{RB}$ ) offers an updated view of the figures, slightly different from that of the previous publications (Omnès 1983; Blanc and Marsan 1984). In particular, it has been possible to replace this art within the chronological and stylistic framework of the Middle and Upper Magdalenian from the Pyrenean and Cantabrian region.

L'ouverture, en 2012, d'une campagne de fouille dirigée par l'un d'entre nous (JMP) dans la grotte Tastet (Saint-Colome, Pyrénées-Atlantiques) a fourni l'opportunité d'une nouvelle analyse des parois ornées de cette cavité. La révision de l'art pariétal (menée par DG, OR et RB), connu depuis les années 1970, fournit une vision actualisée de l'ensemble orné et quelque peu différente des publications antérieures (Omnès 1983 ; Blanc et Marsan 1984). Cette étude permet notamment de replacer ces manifestations dans un cadre chrono-stylistique qui apparaît être celui du Magdalénien avancé (moyen et supérieur) de la région pyrénéo-cantabrique.

\section{INDEX}

Mots-clés: grotte Tastet, Sainte-Colome, Arudy, art pariétal, Magdalénien

Keywords: Tastet cave, Sainte-Colome, Arudy, cave art, Magdalenian

\section{AUTHORS}

\section{DIEGO GARATE}

Université Toulouse II Le Mirail, TRACES (UMR 5608), CREAP, Maison de la Recherche - 5, allée Antonio Machado, FR-31058 Toulouse Cedex 9 - diegogarate@harpea.org

\section{OLIVIA RIVERO}

Université Toulouse II Le Mirail, TRACES (UMR 5608), CREAP, Maison de la Recherche - 5, allée Antonio Machado, FR-31058 Toulouse Cedex 9 - oliviariver@hotmail.com

\section{RAPHAËLLE BOURRILLON}

Université Toulouse II Le Mirail, TRACES (UMR 5608), CREAP, Maison de la Recherche - 5, allée Antonio Machado, FR-31058 Toulouse Cedex 9 - r.bourrillon@gmail.com

\section{JEAN-MARC PÉTILLON}

Université Toulouse II Le Mirail, CNRS, TRACES (UMR 5608), Maison de la Recherche - 5, allée Antonio Machado, FR-31058 Toulouse Cedex 9 - petillon@univ-tlse2.fr 